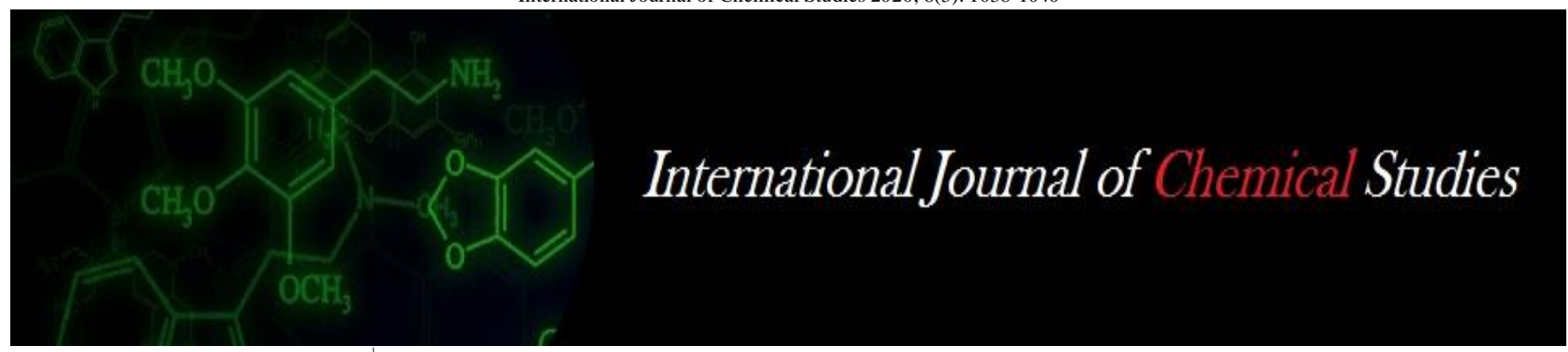

P-ISSN: 2349-8528

E-ISSN: 2321-4902

www.chemijournal.com

IJCS 2020; 8(3): 1038-1040

(C) 2020 IJCS

Received: 20-03-2020

Accepted: 22-04-2020

Binod Kumar

Associate Professor-cum-Senior

Scientist, Department of

Agronomy, MBAC, Saharsa,

Bihar, India

Dr. Pankaj Kumar Ray Subject Matter Specialist (Horticulture), Krishi Vigyan Kendra, Saharsa, Bihar, India

Corresponding Author: Dr. Pankaj Kumar Ray Subject Matter Specialist (Horticulture), Krishi Vigyan Kendra, Saharsa, Bihar, India

\section{Finger millet intercropping with legumes step towards increasing farmer's income}

\author{
Binod Kumar and Dr. Pankaj Kumar Ray
}

DOI: https://doi.org/10.22271/chemi.2020.v8.i3m.9334

\begin{abstract}
A field experiment was conducted during the Kharif season of 2019 at Agronomy Instructional Farm, Mandan Bharti Agriculture College, Saharsa, Bihar Agricultural University, Sabour, Bhagalpur, Bihar, to study the performance of different legumes grown as intercrop with finger millet (Eleusine coracana $\mathrm{L}$.) in different row proportions. Seven different intercropping systems along with sole cropping were tested in Randomized Block Design with three replications. Experimental results revealed that almost all the growth characters of finger millet were significantly higher in sole crop in compared to different intercropping systems. Grain and straw yield of finger millet were significantly high $(2010 \mathrm{~kg} / \mathrm{ha})$ when finger millet was intercropped with black gram at 6:2 pair row ratio among all intercropping system. However, finger millet equivalent yield was significantly high $(2258 \mathrm{~kg} / \mathrm{ha})$ when finger millet was intercropped with black gram at 4:2 pair row ratio among all intercropping system.
\end{abstract}

Keywords: Finger millet, legumes, intercropping, yield, harvest index and biological yield

\section{Introduction}

Finger millet (Eleusine coracana L. Gaertn.), the most important cereal in the dry and rainfed region of world and legumes is the most important crop play a vital role in rained agricultural economy (FAO, 2003) ${ }^{[4]}$. Millets are important staple food crops to the millions of the people in the arid and semiarid regions of the world due to their greater resistance to pests and diseases, good adaption to a wide range of environment and their good yielding capacity and can withstand significant levels of salinity, short growing season, resistant to water logging, drought tolerant, requires little inputs during growth and with increasing world population and decreasing water supplies, represents important crops for future human use. Among millets, Finger millet known as 'Ragi' or 'chodi' is an important crop in India and is a dry land crop cultivated in both tropical and subtropical regions. Finger millet can be able to survive with $28 \%$ of paddy's water needs they are better adapted for current and future droughts. Rurinda $e t$ al., (2014) ${ }^{[11]}$ reported that finger millet provides food security to poor people. Growing of only millets is not much remunerative in the present scenario of agriculture to fulfill the diverse demand of consumers and rapidly growing population. Hence, it is an urgent need of inclusion of the legumes in millet based cropping systems. Initial slow growth of finger millet will facilitate the better establishment of intercrops. Moreover, growing of intercrops will suppress the unwanted weed growth and produces greater output from unit area than sole crop. Earlier, the concept of mixed and intercropping was for subsistence farming, but now a days, this concept has been changed into maximization per unit area and time.

The basic concept of intercropping system involves growing together two or more crops with the assumption that two crops can exploit the environment better than one and ultimately produce higher yield since the component crops differ in resources use and when grown together, they complement each other and make overall better use of resources (Yadav et al., $2015)^{[17]}$. Intercropping with specific planting geometry and selection of compatible crops is a profitable practice to make use of available light, soil moisture and nutrients more efficiently thus, improving productivity of dryland crops (Kaushik and Gautam, 1987) ${ }^{[5]}$. The biggest complementary effect and yield advantages occur when the component crops have different growing periods to make their major demand of resources at different time. 


\section{Materials and methods}

Field experiments were conducted during Kharif 2019 under rained conditions at the Mandan Bharti Agriculture College, Saharsa, Bihar, India. The legume crop of Soybean (JS-9752), Black gram (IPU-2-43) and Groundnut (BG-3) were taken as intercrop in finger millet (GPU-67). The intercrops were sown in finger millet in different row proportions of 4: 2 and 6: 2 . The row spacing of finger millet, soybean, black gram and groundnut were maintained at $20 \mathrm{~cm}, 40 \mathrm{~cm}, 30 \mathrm{~cm}$, and $40 \mathrm{~cm}$ respectively. The legumes crops were sown by dibbling method. The thinning of legume crop was done at 15 days after sowing and only one healthy plant was kept per hill by maintaining the $10 \mathrm{~cm}$ spacing between the two plants. The experiment was laid out in randomized block design with three replications. Ten different treatments were studied viz., T1- Sole crop of finger millet, T2- Sole crop of Soybean, T3Sole crop of Black gram, T4- Sole crop of Groundnut, T5Finger millet + soybean $(4: 2)$, T6- Finger millet + soybean (6:2), T7- Finger millet + Black gram (4:2), T8 -Finger millet + Black gram (6:2), T9- Finger millet + Groundnut (4:2) and T10- Finger millet + Groundnut (6:2). The gross plot size was $23 \times 67 \mathrm{~m}$ and net plot of $6.0 \times 5.40 \mathrm{~m}$. The 5.0 tones of FYM/ ha with recommended dose of fertilizers (60: 40: $25 \mathrm{~kg}$ NPK/ ha) was given to the finger millet crop which was applied through urea and single super phosphate. The crops were sown during the first week of June. Necessary plant protection measures were taken to protect the crop from pest and diseases. The inter cultivation two weeding were followed by one hoeing.

\section{Results and discussion \\ Growth parameters}

All the growth parameters of finger millet were significantly high in sole crop compared to intercropping (Table-1). Nigade et al. (2012) and Ramamoorthy et al. (2004) ${ }^{[9]}$ also reported similar results of low growth characters of finger millet in intercropping. Plant height was affected by intercropping systems and significantly highest plant height $(98.200 \mathrm{~cm})$ was produced under finger millet with black gram (6:2) after 120 days after sowing (Table 1). The effect of different treatments on number of total tillers per plant had significant effect. Significantly the higher numbers of total tillers per plant were produced under finger millet with black gram (45.900) at 6:2 row ratios. This might be due to development of better complementary relationship and non-renewable resources like water, nutrients and incoming sunlight. These results are in close conformity with the findings of Rathore and Gautam (2003) ${ }^{[10]}$. Plant growth is dependent on the rate of accumulation of dry matter. The dry matter accumulation may reflect on the economic yield. Among the intercropping systems, higher total dry matter was recorded in 6:2 row ratio of finger millet with black gram $(340.067 \mathrm{~kg} / \mathrm{ha})$. It was on par with 4:2 row ratio of Finger millet + Black gram (338.600 $\mathrm{kg} / \mathrm{ha}$ ). Significantly lower total dry matter was recorded in sole crop of Finger millet (295.500) (Kiroriwal and Yadav, 2013) ${ }^{[6]}$. High dry matter under intercropping may be due to the weed suppressing capability of intercropping over monocropping (Yih, 1982) ${ }^{[18]}$.

\section{Grain and straw yield}

The sole crop of finger millet recorded the highest grain and straw yield $(2017 \mathrm{~kg} / \mathrm{ha}$ and $4830 \mathrm{~kg} / \mathrm{ha}$ respectively) which was significantly superior over rest of the treatments. Amongst the intercrop treatments, the maximum yield of finger millet $(2010 \mathrm{~kg} / \mathrm{ha})$ was recorded in the treatment of finger millet + black gram (6:2) followed by $(1975 \mathrm{~kg} / \mathrm{ha})$ in finger millet + black gram (4:2). Grain and straw yield of finger millet were reduced considerably when inter cropped with legumes compared with the pure stand of finger millet during the year as reported by Singh and Arya (1999) ${ }^{[14]}$ and Mitra et al. (2001) ${ }^{[8]}$ (Table 2). Such reduction was due to decrease in plant stand compared to that of sole cropping of finger millet. Siddeswaran et al., $1989^{[13]}$ also noticed reduction in grain and straw yields of finger millet under intercropping situation. It was further noticed that sole Soybean recorded the maximum grain and was superior to other intercropping systems. T5- Finger millet + soybean $(4: 2)$ combination recorded the second highest productivity in terms of Grain yield of inter crops which were also greater than those of other intercropping systems during the years. However, T10- Finger millet + Groundnut (6:2) combination recorded the lowest productivity in terms of Grain of inter crops.

\section{Grain equivalent yield of finger millet}

As regards the finger millet grain equivalent yield significantly highest yield, $(2258 \mathrm{~kg} / \mathrm{ha})$ was observed by the treatment T7 where Black gram was taken as intercrop in finger millet in 4:2 row proportion. But it was at par with the treatment T8 where Black gram was taken as an intercrop in finger millet in $6: 2$ row proportions $(2218 \mathrm{~kg} / \mathrm{ha})$. Similar results were also reported by Thorat et al. (1986) ${ }^{[16]}$, Mahadkar and Khanvilkar (1988) ${ }^{[7]}$, Shankarlingappa and Hegade (1992) ${ }^{[12]}$ and Ramamoorthy et al. (2004) ${ }^{[9]}$. It indicates that it is beneficial to raise the finger millet with intercrops rather than sole crop alone.

\section{Harvest index and Biological yield}

A critical analysis of data clearly indicates that there was significant variation in harvest index due to different treatments. The data revealed that the maximum harvest index (HI) was observed $(338 \%)$ in Finger millet + Black gram (4:2) which was at par with Finger millet+ Black gram (6:2). Minimum harvest index (339\%) was recorded under sole crop of finger millet (T1) treatment. This reduction in harvest index of finger millet is attributed by Bhowmik et al., $2012^{[2]}$. Among various intercropping systems, biological yield was the highest with $6: 2$ row ratio in Finger millet + Black gram $(6834 \mathrm{~kg} / \mathrm{ha})$ and 4:2 row ratio in Finger millet + Black gram $(6676 \mathrm{~kg} / \mathrm{ha})$. Corresponding decrease in biological yield of finger millet at 4:2 row ratio. This reduction in biological yield of finger millet is attributed to decrease in proportionate area of finger millet in intercropping (Chandra et al., 2009a) [3].

Table 1: Growth parameters of finger millet at different stages as influenced by different treatments

\begin{tabular}{|c|c|c|c|c|c|c|c|c|c|c|c|}
\hline \multirow{2}{*}{ Treatments } & \multicolumn{4}{|c|}{ Plant height (cm) } & \multicolumn{4}{|c|}{ No of tillers } & \multicolumn{3}{|c|}{ Dry matter (kg/ha) } \\
\hline & 30 DAS & 60 DAS & 90 DAS & 120 DAS & 30 DAS & $60 \mathrm{DAS}$ & 90 DAS & $120 \mathrm{DA}$ & 30 DAS & S60 DAS 90 DAS & 120 DAS \\
\hline T1- Finger millet (Sole) & 18.200 & 67.200 & 92.900 & 98.400 & 24.900 & 49.867 & 47.900 & 46.000 & 22.100 & 176.100280 .200 & 341.633 \\
\hline T2- Soybean (Sole) & & & & & & & & & & & \\
\hline T3- Black gram (Sole) & & & & & & & & & & & \\
\hline
\end{tabular}


T4- Groundnut (Sole)

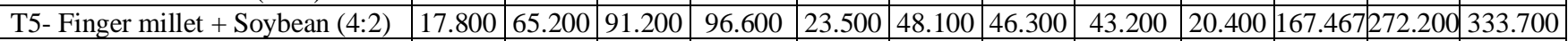

\begin{tabular}{|c|c|c|c|c|c|c|c|c|c|c|c|}
\hline T6- Finger millet + Soybean $(6: 2)$ & 18.000 & 65.600 & 91.500 & 97.000 & 23.800 & 48.500 & 46.700 & 43.833 & 20.733 & 169.333273 .300 & 335.367 \\
\hline
\end{tabular}

\begin{tabular}{|l|l|l|l|l|l|l|l|l|l|l|l|}
\hline T7- Finger millet + Black gram (4:2) & 18.400 & 66.900 & 92.300 & 97.900 & 24.500 & 49.400 & 47.200 & 45.700 & 21.667 & 175.000276 .200 & 338.600 \\
\hline
\end{tabular}

\begin{tabular}{|l|l|l|l|l|l|l|l|l|l|l|l|}
\hline T8- Finger millet + Black gram (6:2) & 18.600 & 67.100 & 92.700 & 98.200 & 24.700 & 49.700 & 47.600 & 45.900 & 21.967 & 175.400277 .500 & 340.067 \\
\hline
\end{tabular}

\begin{tabular}{|l|l|l|l|l|l|l|l|l|l|l|l|}
\hline T9- Finger millet + Groundnut (4:2) & 18.200 & 66.300 & 91.500 & 97.500 & 24.000 & 48.900 & 46.800 & 45.100 & 20.367 & 173.500274 .300 & 336.133 \\
\hline
\end{tabular}

\begin{tabular}{|c|c|c|c|c|c|c|c|c|c|c|c|}
\hline T10- Finger millet + Groundnut (6:2) & 18.400 & 66.700 & 91.800 & 97.800 & 24.300 & 49.100 & 47.000 & 45.400 & 21.600 & 173.800275 .500 & 337.533 \\
\hline
\end{tabular}

\begin{tabular}{|c|c|c|c|c|c|c|c|c|c|c|c|c|}
\hline & & & & & & & & & & & & \\
\hline SEM & 0.233 & 0.249 & 0.120 & 0.086 & 888 & 0.227 & 0.060 & 0. & 0.261 & 0.158 & 0.493 & 0. \\
\hline 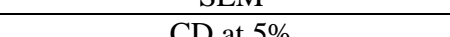 & & 0.776 & 0.373 & 0.267 & \begin{tabular}{|l|}
0.274 \\
\end{tabular} & 0.707 & 0.186 & 0.267 & 0.813 & 0.493 & 1.534 & 0 \\
\hline
\end{tabular}

Table 2: Grain and Straw yield, Grain/haulm/pod yield of inter crops, Finger millet equivalent yield, Biological yield and Harvest Index of Finger millet as influence by different treatments

\begin{tabular}{|c|c|c|c|c|c|c|}
\hline Treatments & $\begin{array}{c}\begin{array}{c}\text { Grain yield of } \\
\text { Finger millet } \\
(\mathrm{Kg} / \mathrm{ha})\end{array} \\
\end{array}$ & $\begin{array}{c}\text { Grain/haulm/pod } \\
\text { yield of inter crops } \\
\text { (Kg/ha) }\end{array}$ & $\begin{array}{c}\text { Finger millet } \\
\text { equivalent } \\
\text { yield (Kg/ha) }\end{array}$ & $\begin{array}{c}\text { Straw yield of } \\
\text { Finger millet } \\
(\mathrm{Kg} / \mathrm{ha})\end{array}$ & $\begin{array}{c}\text { Biological } \\
\text { yield } \\
\text { (kg/ha) }\end{array}$ & $\begin{array}{c}\text { Harvest } \\
\text { Index } \\
(\%) \\
\end{array}$ \\
\hline T1- Finger millet (Sole) & 2017 & & & 4830 & 6847 & 339 \\
\hline T2- Soybean (Sole) & & 1565 & 1843 & & 4147 & 264 \\
\hline T3- Black gram (Sole) & & 1285 & 2325 & & 3020 & 235 \\
\hline T4- Groundnut (Sole) & & 1425 & 2302 & & 4660 & 327 \\
\hline T5- Finger millet + Soybean $(4: 2)$ & 1831 & 1435 & 1690 & 4248 & 6079 & 332 \\
\hline T6- Finger millet + Soybean $(6: 2)$ & 1865 & 1325 & 1560 & 4290 & 6155 & 330 \\
\hline T7- Finger millet + Black gram (4:2) & 1975 & 1248 & 2258 & 4701 & 6676 & 338 \\
\hline T8- Finger millet + Black gram (6:2) & 2010 & 1226 & 2218 & 4824 & 6834 & 340 \\
\hline T9- Finger millet + Groundnut (4:2) & 1905 & 1305 & 2108 & 4382 & 6287 & 330 \\
\hline T10- Finger millet + Groundnut (6:2) & 1933 & 1275 & 2060 & 4465 & 6398 & 330 \\
\hline SEM & 5.893 & 2.981 & & 3.936 & & \\
\hline $\mathrm{CD}$ at $5 \%$ & 18.360 & 9.013 & & 12.262 & & \\
\hline
\end{tabular}

\section{Reference}

1. Bhatnagar SK, Yadav OP, Gautam RC. Research achievements in pearl millet (Pennisetum glaucum). Ind. J. of Agril. Sci. 1998; 68:423-430.

2. Bhowmik SK, Sarkar MAR, Zaman F. Effect of spacing and number of seedlings per hill on the performance of ausrice cv. NERICA 1 under dry direct seeded rice (DDSR) system of cultivation. J. of the Bangladesh Agril. Univ. 2012; 10(2):191-195.

3. Chandra A, Sharmila P, Pardha Saradhi P, Rao KS, Saxena KG, Kandari LS et al. Assessment of Biological Yield of Some Selected Vigna sps. with Native Rhizobial Strain in Traditional Agro ecosystem of Central Himalaya. Proceeding of International Conference on Changing Environmental Trends and Sustainable Development, Hisar, 2009a, 217-221.

4. FAO. Production Year Book, 2002. Food and Agriculture Organization of the United Nations (FAO), Rome, Italy, 2003. http:/ apps.fao.org.

5. Kaushik SK, Gautam RC. Effect of nitrogen and phosphorus on the production potential of pearlmilletcowpea or green gram intcrcropping systems under rainfed conditions. The J. of Agril. Sci. 1987; 108(2):361-364.

6. Kiroriwal A, Yadav RS. Effect of Intercropping Systems on Intercrops \& Weeds. Int. J. Agric. Food Sci. Tech. 2013; 7(4):643-646.

7. Mahadkar UV, Khanvilkar SA. Studies on intercropping of Kharif ragi with grain legumes. J. Maharashtra agric. Univ. 1988; 13(3):364-366.

8. Mitra S, Ghosh DC, Sundra G, Jana PK. Performance of intercropping legumes in finger millet at varying fertility levels. Ind. J. Agron. 2001; 46(1):38-44.

9. Ramamoorthy KA, Christopher L, Alagudurai S, Kandawamy OS, Murgaappan V. Intercropping pigeon pea (Cajanas cajan) in finger millet (Eleusine coracana L.) on productivity and soil fertility under rainfed conditions. Ind. J. Agron. 2004; 49(1):28-30.
10. Rathore SS, Gautam RC. Agro techniques to improve the productivity of pearl millet + cowpea intercropping system under dry land conditions. Ann. Agric. Res. 2003; 24:971-975.

11. Rurinda J, Mapfumo P, Van Wijk MT, Mtambanengwe F, Rufino MC, Chikowo R. Comparative assessment of maize, finger millet and sorghum for household food security in the face of increasing climatic risk. Euro. J. of Agron. 2014; 55:29-41.

12. Shankarlingappa BC, Hegade BR. Intercropping studies in finger millet with pigeon pea and field bean. Mysore J. agric. Sci. 1992; 26:248-253.

13. Siddeswaran K, Ramasamy C, Morachan YB. Nutrient uptake of finger millet as influenced by intercrops, border crops and N fertilization. Madras Agril J. 1989; 76(7):361-365.

14. Singh RV, Arya MPS. Nitrogen requirement of finger millet (Eleusine coracana L.) + pulse intercropping system. Ind. J. Agron. 1999; 44(1):47-50.

15. Sobkowicz P. Competition between triticale and field beans in additive intercrops. Plant Soil Environment. 2006; 52:47-56.

16. Thorat ST, Sonune SP, Chavan SA. Intercropping of some pulse and oilseed crops in Kharif ragi. J. Maharashtra agric. Univ. 1986; 11(3):268-271.

17. Yadav BL, Patel BS, Ali S, Yadav SK. Intercropping of legumes and oilseeds in summer pearl millet [Pennisetum glaucum (L.) R.Br. Emend. Stuntz]. Legume Res. 2015; 38(4):503-508.

18. Yih WK. (1982). Weeds, intercropping and mulch in temperate zones and the tropics-Some ecological implications for low technology agriculture. Ph.D. thesis. University of Michigan, Ann, Arbor, MI. Yunusa, I.A.M., 1989. 